\title{
Discriminatory Property Inheritance Rights Under The Yoruba And Igbo Customary Law In Nigeria: The Need For Reforms**
}

\author{
Dr Babatunde Adetunji Oni \\ Senior Lecturer, Faculty of Law, University of Lagos, Akoka, Lagos, Nigeria.
}

\begin{abstract}
Intestate succession under customary law among the Yoruba and Igbo people in Nigeria is full of discrimination, especially to female, adopted child, illegitimate child among others. This paper highlights some of these forms of discrimination and the dangers inherent in them. The paper discovers that some of these forms of discrimination are against Fundamental Human Rights which frown against discrimination to any persons irrespective of their gender, circumstances of birth or age. The paper suggests necessary reforms to curb some of these identified discrimination.
\end{abstract}

\section{Introduction:}

The law of succession involves the transmission of the rights and obligations of the deceased person in respect of this estate to his heirs and successors. It equally deals with the rules governing the administration of the estate by the personal representatives of the deceased person including state participation in respect of the real estate situate within its territory and personal estate of the deceased person subject to its jurisdiction. ${ }^{1}$

Succession may be testate or intestate. Where a deceased person made a will, he is said to have died testate. Where a deceased's person did not make a will, he is said to have died intestate. In customary law, this distinction is of marginal importance because under customary law, intestacy is the rule. The only consideration of a testate succession under customary law is a nun-cupative will, also known as death bed declaration. ${ }^{2}$

Inheritance issues are varied across the length and breadth of Nigeria. The law of succession and inheritance is a reflection of the legal pluralism inherent in Nigeria. In general, in cases of inheritance of property of a person who dies intestate in Nigeria, the personal customary law of the deceased that is, customary law to which the deceased was subject, governs the distribution of his estate. The system of customary inheritance varies from one ethnic group to the other. The class of people who should benefit from intestate succession and the share of such beneficiary is not free from problems.

The aim of this paper is to critically analyse the problems generated as a result of discrimination of property inheritance rights under the various customary law with particular reference to the customary laws of the Yoruba and the Igbo in Nigeria and its effects on the rights of women, daughter, illegitimate children and adopted children. The paper discussed the various discriminatory practices and proffer solutions and possible reforms.

\section{An Analysis Of The Rules Of Intestacy Under The Vaious Customary Laws}

Nigeria has over two hundred and fifty (250) ethnic groups and even greater number of customary laws. The distribution of a deceased's estate under customary law is based on the customary doctrines of inheritance and succession of property. These doctrines are governed by the canons of lineal descent along paternal or material lines. ${ }^{3}$ Paternal lines are lines of descent traced through the father, maternal lines are lines traced through the mother. For instance, the line of descent governing inheritance of the people in Yoruba is paternal while that governing the people of Afikpo, Abriba and Ohafia in the Eastern part of Nigeria is maternal. ${ }^{4}$

When a deceased dies intestate, his personal customary law governs the distribution of his estate irrespective of where the property is situated or where the death occurred. ${ }^{5}$ In Tapa V. Kuka ${ }^{6}$ The deceased was

\footnotetext{
${ }^{1}$ Babatunde Oni: "The Rights of Women to Inheritance under Nigerian Law: An Evaluation" Nigerian Journal of African Law (2008) 2 NJAL pg. 40.

2 Ibid.

${ }^{3}$ T.O.G. Animashaun \& A.B. Oyeneyin: Law of Succession, Wills and Probate in Nigeria: M.J Publisher Ltd (2003) p.3

${ }^{4}$ See Prof. U.U. Uche in this articled "The Matrilineal System of Inheritance. The Nigeria Model" in Towards a Restatement of Nigerian Customary Laws (1991) Federal Ministry of Justice page 174 at 177.

${ }^{5}$ See Section 25(2) of the Customary Court Edict, 1997 of Delta, Section 20(2) Customary Court Law Cap 31 of Western Nigerian 1959, Section 15 Customary Court Edict 1966 of Eastern Nigeria.
} 
a Nupe of Bida who died intestate leaving landed property in Lagos. It was held by Brooke J, that the law to be applied in determining who was entitled to administer the estate was the deceased's personal law of Nupe and not that of Lagos.

However, where the deceased during his life time adopted the law of the area of jurisdiction as his personal law, then that law would govern the administration of his estate.

In Olowu V. Olowu ${ }^{7}$ the deceased was a Yoruba of Ijesha by birth, who; lived all his life in Benin City. He married Bini women and acquired property there. He naturalized as a Bini man. He died intestate and his estate was distributed under in native law and custom.

The provisions of Section 24(a) of the Land Use Act, provides that the applicable law is the customary law of the place where the land is situate (Lex situs), where the occupier is a native of the occupier is a native of the place or by contract, statue or special custom. But if it is established that the occupier is governed by any other customary law which is his personal law will apply. This provision may have reversed the general principle that was stated in Aishatu V. Coker. $^{8}$

With the above exposition to the background of customary laws and practices governing intestate inheritance, some customary law rules on succession in Nigeria will now be examined.

\section{The Yoruba Customary Law Of Inheritance}

The Yoruba people occupy South-western Nigeria and; spreads into some part of the People's Republic of Benin (formerly Dahomey) and Togo. ${ }^{9}$

As far as historical memory extend, the Yoruba have been the dominant group on the west bank of the Nigeria. Portuguese explorers "discovered" the Yoruba cities ad kingdoms in the fifteenth century, but cities such as Ife and Benin, among others, had been standing at their present sites for at least five hundred years before the European arrival.

The Yoruba homeland is roughly the size of England and comprises a number of sub-ethno cultural groups which include Ife, Igbomina, Kwara, Egaba, Ondo, Ilaje, Abeokuta, Ikale, Idanre, Ekiti, Ibadan, Owo Oyo, Shabe, Ijebu, Ijesha, Ketu, Anago, Egbado, Ifonyin and Awon. ${ }^{10}$ The Yoruba are usually thought to be unique in number and size of their towns because of their tendency to form into large city groups instead of small village groups.

The native law and customs among the Yoruba, especially in respect to inheritance and succession, have grown out of the age-long practices and dealings of the people. The Yoruba customary law of inheritance and succession appears to be general among the constituent Yoruba States. This, however, is not to say that there are no few differences among the sub-ethno cultural groups. For example, findings ${ }^{11}$ have shown that among the Ijesha people mode of inheritance is belineal. Among the Ijebus, it is patrilineal (although women can inherit). And for the Ilaje and Idanre people of Ondo State, it is bilineal.

Under the Yoruba Native Law and Custom, it was the brothers and sisters (of full blood) of the deceased who were entitled to inherit property. ${ }^{12}$ However, the tendency now is to excise the brothers and sisters and limit the right to inherit property to the children of the deceased. The rights of the brothers and sisters are in some areas only curtailed but not abrogated. For example in Abeokuta they are still entitled to onethird $(1 / 3)$ of the deceased property. ${ }^{13}$ However a testator by Will may enlarge his family to include brothers and sisters.

In Sogbesan V. Adebiyi ${ }^{14}$, the deceased founder of the family devised his property to his heirs as family house. In his Will, he appointed one of his brothers as the head of family. The court held that the Will as a whole made it clear that the testator intended the word "family" to include his brothers and sisters and their descendants as well as his own children.

\footnotetext{
${ }^{6}$ (1945) 18 NLR 5.

7 (1985)3 NWLR, (PT 13), 372 (1985) 12 SC 84.

8 (1945) 18 NLR 5.

${ }^{9}$ See Fadipe, N.A. The Sociology of the Yoruba, Ibadan (1970), University of Ibadan Press p. 40.

${ }^{10}$ Lloyd, P.C. The Yoruba of | Nigeria in Peoples.

11 Mainly from interviews

${ }^{12}$ A.B. Kasumu J.W. Salacuse Family Law Revised ed.) (Butterworth London) pg. 291.

${ }^{13}$ A.B. Kasumu and J.W. Salacuse Family Law Ibid pg. 29137. (1941) 19 NO 26.

14 (1992)5 NWLR (Pt 242) pg. 503.
} 
According to Yoruba Native Law and Custom, if an individual dies intestate, his children both male and female succeed to the estate as a single entity as was held in Amadi V. Obayomi. ${ }^{15}$ As joint owners of the property they have the right to ingress and agrees and to attend meetings therein. The eldest son known as Dawodu inherits the responsibility for the management of the estate. In dealing with this point Osborne CJ in Lewis V. Bankole $^{16}$ said that this was a well-established rule both in Lagos and in other parts of Yorubaland. It was however on the death of the Dawodu; he said, that variations would begin. However, it has been a laid down general rule of inheritance among the Yoruba that the eldest son succeeds to the land in the place of his father for his own benefit and that of the family. ${ }^{17}$ The children and wives though have the right of live in the house. The widow who takes another husband loses her right. The son had no right sell the land or the house for the holds it in trust for the family.

Accepting that the rationale for keeping the headship in the male line is that the women on marriage go to live with their husbands, the Chief Justice nonetheless accepted the evidence of the chiefs that what was really important in this role was the mental and cultural competence of the family head.

The children succeed to the deceased's property as family property. The concept of family property really belongs to the field of land law but a short description of the concept is necessary for a proper understanding of the law of succession. Under customary law particularly in the southern parts, the main unit of land holding is through the family. A person has to be identified with a family before he can claim land. When part of the communal land that is land belonging to the community is given to the founder of the family for his use, such land on the death of the founder will devolve on his family. The title is vested in the family of the founder as a corporate group. It is joint and indivisible and no part of it is capable of being alienated absolutely by an individual member without the consent of the other family members. ${ }^{18}$

It should of course be mentioned that family property is not limited to a residence nor is it necessary that he deceased should expressly provide that it must be used as family property. The creation of family property is automatic on a death intestate. Family in this context often means the immediate family that is the children of the deceased.

Under the traditional customary law, factors like age and sex often affect the scale of distribution. A female child regardless of her age might be made to take last and her share might also be smaller when compared to the entitlements of her brothers. However, since the decision in Lopez V. Lopez ${ }^{19}$ where Combe CJ confirmed that, originally, the rules of the daughters in Yorubaland were not the same as sons with regards to their father's property, he went on to hold that both sons and daughters can inherit equally. This decision has been followed in a number of cases. In Salami V. Salami ${ }^{20}$ it was held that the plaintiff's right to inherit her father's estate along with her two brothers was not diminished by the fact that she was a girl.

In Richardo $V . A_{b a l^{21}}$ not only did the court accept the proposition that a female child has inheritance rights, but it went further to hold that when a man dies leaving two houses and two children, male and female, the female if older has the first choice as to which house she wants the property is eventually partitioned. ${ }^{22}$

It is also relevant in this connection to note S. 20(4) of the Western Nigeria Customary Law, which provides thus:

Where the customary law applying to land prohibits restricts, or regulates the devolution on death to any particular class of persons of the right to occupy such land, it shall not operate to deprive any person of any beneficial interest in such land (other than the right to occupy the same or proceeds of sale therefore to which he may be entitled under the rules of inheritance or any other customary law).

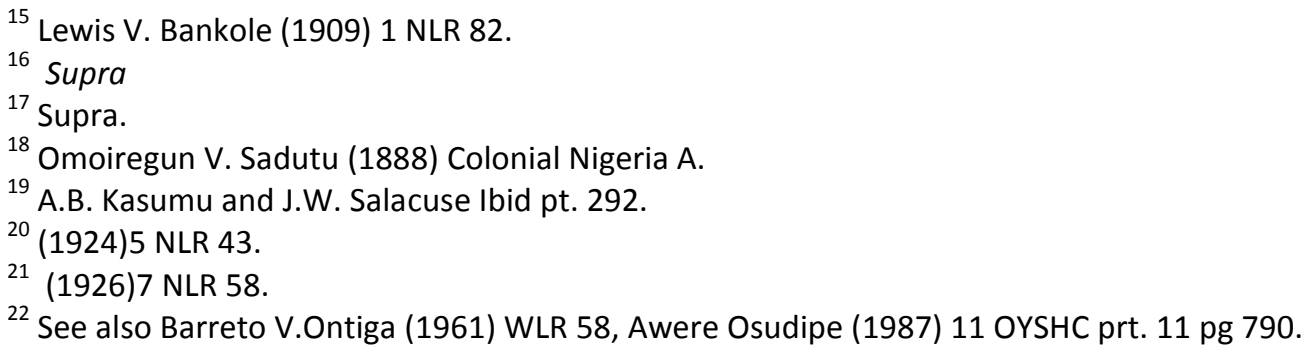


The effect of this provision is that even when a female child is not entitled to occupy land under the succession laws of any area in Western Nigeria, such a child will still be entitled to the proceeds derived from the land. ${ }^{23}$

"Where the deceased intestate married only one wife and had all his children by her, the distribution of the estate among them is equal proportion, hence little or no dispute occurs, but if the deceased intestate had children by different wives or women, the distribution of estate may raise questions as to what mode of distribution should be adopted. This is because the women may have unequal number of children for the deceased intestate.

It is a rule of Yoruba customary law that an intestate estate may be distributed among the children by the Idi Igi mode that is per stripe or the Ori Ojori mode that is per capital. ${ }^{24}$ In an examination of the two modes of distribution, Obilade ${ }^{25}$, described the Idi Igi mode of distribution as:

A custom whereby the property of the deceased is divided among his children per stripes (the property being first divided equally into the number of wives, the share attributable to each wife being then sub-divide equally among her own children).

The rationale for the Idi-Igi mode of distribution was considered by the Learne Jibowu $J$ in Danmole V. $D_{a w o d u^{26}}$ as being that each wife who had a child was given no cause for jealously against the others. Therefore the number of wives and not the children is the determinant factor.

In Taiwo V. Lawani ${ }^{27}$ it was held that according to the Native Law and custom of the Yoruba people of Lagos State, there is custom known as Igi kan kan or idi-Igi, where the property of the deceased intestate is distributed among his children according to the number of mothers (wives of the deceased). Each mother is regarded as constituting a branch of the family for the purpose of succession. An only child of a wife will get the same share as with the many children of another wife. It was further held that the rule of succession known as Igi kan kan or Idi-Igi which regulates the distribution; of customary estate of the deceased intestate is a well recognized and established native law and custom and it was also held that Igi kan kan or Idi-Igi is not repugnant to natural justice, equity and good conscience.

In the Ori Ojori mode of distribution, each child enjoys an equal share, it has been argued that this mode of likely to produce fairness and thereby prevent dispute and dissention in the family.

Conversely, that an adoption of the Idi-Igi is more likely to bring about disharmony within the family as it would be unfair to the children of a particular wife with more siblings. ${ }^{28}$

Whereas the right of daughters to inherit their father's property has been rec9ognized under Yoruba Native Law and Custom, wives have no right of inheritance e in their deceased husbands estate. As Jibowu FJ, observed in Suberu V. Sunmonu ${ }^{29}$ It is a well settled rule of native law and custom of the Yoruba people that a wife could not inherit her husband's property since she herself is, like a chattel, to be inherited by a relative of her husband".

Earlier, in Sogunro-Davies V. Sogunro-Davies ${ }^{30}$, Beckley J had opined that Yoruba native Law and Custom deprived the wife of inheritance right in her deceased husband's estate because devolution of property follows the blood.

\footnotetext{
${ }^{23}$ A.B. Kasumu and J.W. Salacuse Ibid pg. 293.

${ }^{24}$ A.B. Kasumu and J.W. Salacuse Ibid Pg 292, El. Nwogugu Family Law in Nigeria (revised ed), Heinemann Educational Books. Pg 311-312.

${ }^{25}$ A.O. Obilade, The Nigeria Legal System, (Revised ed) Sweet and Maxwell: London (1979) pg 86-87

${ }^{26}(1958) 33$ FSC 46.

${ }^{27}$ (1961) ANLR 733.

${ }^{28}$ MC Okany, Commercial Law in Nigeria, (Revised edition) pg 692.

${ }^{29}$ (1957)12 FSC 33.

30 (1928) 8 NLR 79
} 
Consequently, unless a property given to a wife is proved to be an outright gift, it will pass on the husband's death as family property to be inherited by the husband's children or the husband's family where there are no children. The wife has no right of inheritance whatsoever.

\section{Igbo Customary Law}

The rules of customary law on succession in Igboland are not uniform. However, certain similarities can still be identified.

The Igbos of |Nigeria are found predominantly in Anambra, Imo, Enugu, Ebonyi and some parts of Rivers and Delta States. The cardinal principle of customary law of succession among the Ibos is |Primogeniture that is succession by the first born of the line. ${ }^{31}$ This principle, which is also prevalent in the customary laws of other ethnic groups in Nigeria, determines the right to inherit property in Igbo land and therefore the interest of all persons related in one way or the other to the deceased. The exception to this rule 0065ists in Afikpo and Bende areas of Ebonyi and Abia States which are bilineal, ${ }^{32}$ where women have full legal capacity to own land and to transmit their rights and interests to others either intervivos or death.

Under the principle of primogeniture, succession is through the eldest male in the family who is known as 'Okpala, Diokpala or Diokpa'. In the case of a nuclear family, succession is through the eldest male child of the deceased. With regard to the extended family, succession is through the eldest son of the ancestor and so on in that line irrespective of the fact that the Okpala may in fact be junior in age to other members of the extended family.

On the death of the founder of a family, his eldest son succeeds him as the head of the family. The eldest son is entitled to special property by virtue of his status in the family. He enjoys this property during his life time to the exclusion of his brothers. He is entitled to reside in his father's dwelling house. Subject to accommodation required by his own family, he may allow his younger brother and sisters to live in this house with him. He is also entitled to the use of the piece of land within or surrounding the father's compound and to harvest the economic trees in it such as palm, coconut and kola-trees. Other immovable property which is allocated to the eldest son in addition to his father's dwelling house and compound land from one place of another. Among the Ibos in Okigwe, he is given another piece of fertile land called ala Iasi Obi. In Orunba, Mbaise, Udoka and Agudo all in Awka he is shown a piece of farm land by the administrators of the estate in Ogoni, he is entitled to a piece of farm land and in Annang, he is shown a fertile piece of land and a palm bush. $\mid \mathrm{He}$ is also entitled to the dresses which his father wore in special occasion together with his walking stick. ${ }^{33} \mathrm{He}$ also inherits his father's personal ofo and other objects of worship. Where a title survives the holder, the eldest son inherits the father's title. He is also entitled to the insignia of a hereditary office which he has no right to sell, being family property. ${ }^{34}$

In Ejiamike V Ejiamike, ${ }^{35}$ the court found an evidence that in accordance with Onitsha Customary Law, the eldest son has the right to manage and administer the real estate of his deceased father for the benefit of himself and his brothers. According to Mr. G.T Basden 'Personal property descended to the eldest son as heir or failing a son to the eldest brother or male relative. ${ }^{36}$

Under Igbo Customary Law, Females do not possess the rights to inherit and, that is, neither the daughters nor the widows of the deceased have the right in the intestate estate of the deceased. In Ugboma V. Ibeneme $^{37}$ where it was held in accordance with the general Ibo custom which is also the custom of the deceased home in Anambra Local Government Area, women are not entitled to inherit land from their father. Consequently, the female plaintiffs have no locus standi in such action.

In Nezianya V. Okagbue ${ }^{38}$ it; was held that possession by a widow of her husband's land cannot be adverse to the right of her husband' family to enable her acquire an absolute right to possession of it against the family.

\footnotetext{
31 E.I. Nwogugu.

32 Babatunde Oni, (Supra) N.1

${ }^{33}$ Nwakanma Okoro. The Customary Laws of Succession In Eastern Nigeria and The Judicial Rules Governing their Application London: (Revised ed) (Sweet and Maxwell (1966) pg 118-119.

34 E.I. Nwogugu, Ibid.

35 (1972)2, E.S.L.R. 11,; see also Ngwo V Onyejana (1963) 1 ALL NLR 352.

${ }^{36}$ Niger Ibos Chapter XIX Land Tenure and Inheritance, pg 268.

${ }^{37}$ (1967) F.N.L.R. 251.

38 (1963) 1 ALL, NLR 352
} 
Although a widow cannot alienate any part of the deceased's estate, she is entitled to live on the deceased husband's house as a member of the family until she remarries or dies. The Diokpa has no right under native law and custom to dispose of the property occupied by her without an alternative accommodation so long as she behaves well. ${ }^{39}$

Daughters, like wives, do not inherit under Igbo customary law. ${ }^{40}$ A daughter can only inherit were she accepts to remain unmarried in her father's house with a view of raising sons in her father's name

This is known as "Nrachi"41 or "Idigbe" institution. It usually happens when the deceased left behind a substantial estate but no surviving sons or other male issue of the lineage to inherit it. The idea behind this practice is to save the lineage from extinction. The daughter as an "Idegbe" or Nrachi is entitled to inherit both movable and immovable property of her deceased father's estate. The legal interest vests in her until she gives birth to her own children. However, if she bears sons and daughters, the sons and not the daughters will succeed her in accordance with the rule of primogeniture.

Daughters have no right of inheritance over their mother's landed property. Where a wife predecease her husband, the sons will inherit and failing, the husband inherits and failing his male relatives.

In some parts of Igbo land where the intestate died without sons, brothers or father, his estate is inherited by his eldest nearest paternal male relation. Such relation is known as "Oriekpe" while the custom is known as "IriEkpe" Custom.

In Mojekwu V. Mojekwu, ${ }^{42}$ the deceased owner had two females surviving him, his male nephews claimed to be entitled to his estate. The Court of Appeal (per Tobi J.C.A.) rejected the view that the case was governed by Nnewi Customary Law but added that even if this were so, such a customary law which discriminated against women, would not be enforced as it would be repugnant to natural justice, equity and good conscience. However, the Supreme Court rejected the decision of the Court of Appeal and upheld the 'Iri ekpe' custom.

While a daughter is not entitled to inherit her father's estate, she has the right to be maintained by the person who inherits her father's estate until she marries or becomes financially independent or dies.

In the estate of Agboruja, ${ }^{\mathbf{4 3}}$ the court held that the custom whereby the eldest brother of the deceased or male relative inherits his deceased brother's property is widespread throughout Nigeria. Yet it is not equitable because such male relative would thus become a new father to the children and be responsible for their upbringing as if they were his own. It was also held to be perfectly permissible that such a male relative of the deceased should be able to inherit the latter's wife if she agrees.

The inheritance of the wife and children of a deceased man by his younger brother, a system known as levirate marriage, is a scheme of social insurance against neglect and hunger of the decease dependent. ${ }^{44}$

\subsection{THE RIGHT OF SPOUSES}

\section{Victims Of Discriminatory Property Rights Under Cdustomary Law}

On the death intestate of a husband, dispute often arises as to whether his widow can inherit his property. Whether a widow can inherit the intestate estate of her husband will depend on the customary law of his locality, ${ }^{45}$ the husband may during his life-time allocate a house or land for the use of his wife. Unless an outright gift is proved, the property allocated to the wife will on the death of the husband still pass as a family property. Thus in Oloko V. Giwa ${ }^{46}$ there was an allocation of family land to each of the wives of the deceased. It was held that the effect of the allocation was not to confer title or give any right on such properties to the wives.

39 Ogboine; R.A. Bendel Land Law Services No 4 Oshimili and Aniocha. "Their People and Land Tenure"

40 Mojekwu V Mojekwu (1999)7 NWLR (pt 215) pg. 283.

${ }^{41}$ Nwogugu, Family Law in Nigeria (1974) Heinemann Studies in Nigeria Law pg. 402.

42 (1997)7 NWLR (pt 512) 283.

43 (1949) 19 NLR 38.

${ }^{44}$ See T.O. Elias, Impact of English Law up9on Nigerian Customary Law (1960) pg 19.

${ }^{45}$ Family Law, Margaret Chinyere Onokah ibid. pg 355.

${ }^{46}$ (1939) 15 N.L.R. 31 Dosunmu V Dosumu (1954) 14 WACA 527 
Similarly, in Caulcrick V. Harding ${ }^{47}$ it was held that a husband was not entitled to succeed to the property of the wife under customary law. The property involved in the two cases above was unpartitioned family property. It is submitted that the same decision could be reached in respect of the self acquired property of the spouses. The rule that the spouses have no succession rights in the property of each other seems to be universally acknowledged principle under most of the customary law system in Nigeria. ${ }^{48}$

Thus, in Nezianya V. Okagbue, ${ }^{49}$ the land in dispute was situated at Onitsha and all the parties were natives of Onitsha also. On the death of the husband, his widow began letting his houses to tenants. Later on she sold a portion of the land and with the proceeds she built two mud huts on another portion of the land. When she wanted to sell more parcels of land, her later husband's family objected. The only child she had for her husband was a girl who predeceased her. The widow devised the property to the late daughter's child who now sued the husband's family claiming right to exclusive possession of the gr9ounds that the widow, their grand mother had long adverse possession on the land. In the trial court it was held that possession by a widow of her husband's land cannot $b$ e adverse to the rights of her husband's family to enable her acquire an absolute right to possession of it against the family. One appeal to the Supreme Court by the plaintiff, the court observed that:

It will appear that the essence of passion of the wife in such a case is that she occupies the property or deals with it as a recognized member of her husband's family and not as a stranger, nor does she need the express consent or permission of the family to occupy the property so

long as the family make no objection to her occupation.

From the evidence it is abundantly clear that a married woman after the death of her husband can never under native law and custom be a stranger to her deceased husband's property, she would not at any time acquire a distinct possession of her own to oust the family's right of ownership over the property. The Onitsha native law and custom postulate that a married woman on the death of her husband without a male issue, without the concurrence of her husband's family, may deal with his (deceased) property. Her dealings, of course must receive the consent of the family. The consent, it would appear, may be actual or implied from the circumstances of the case, but she cannot assume ownership of the property or alienate it. She cannot by effluxion of time claim the property as her own. If the family does not give their consent, she cannot, it would appear, deal with the property. She has however right to occupy the building or part of it, but this is subject to good behaviour.

According to the authorities, under the Yoruba customary marriage law, separate houses or rooms allotted to the wives by their polygamist husband does not vest in the wives, as such allotments are not outright gifts. Upon his death, such houses or rooms become part of the real property of the deceased which devolve on his family. ${ }^{50}$ Moreover, where a husband in his Will ; purports to vest the unpartitioned family property in his wife, it is not capable of devolving upon the widow as such property consists of rights which are purely communal and inalienable, and where such property is being distributed by the family members, the widow cannot successfully claim that she is entitled to the share which would have been her husband's had been alive. This s because devolution of family property under customary law "follows the blood" 51

The rationale behind this rule is that family land must be kept intact. There is also the fact that the deceased intestate's customary law wife is not a member of the family for this purpose. This is evidence in the statement by Coker $^{52}$ that among the Yoruba's of Nigeria the wives of a man also constitute part of his property."

In Suberu V. Sunmonu ${ }^{53}$ the question for decision was which of the two parties, the maternal or paternal relations- should inherit the real estate. The court held that as the deceased son died intestate without an issue, his share of the family house developed upon his uterine brother's children. The court also declared. "It is a well settled rule of native law and custom of the Yoruba people that a wife could not inherit her husband's property."

47 (1926) 7 N.L.R. 48

${ }^{48}$ A.B. Kasumu and J.W. Salacuse ibid. pg 297.

${ }^{49}$ (1963) 1 ALL N.L.R. 352.

50 Per Graham Paul in Oloko V. Giwa (supra).

${ }^{51}$ Sogunro Davies V. Sogunro Davies \& others (1929) 9 N.LR. 79.

${ }^{52}$ Coker; G.B.O. (ibid) p. 39

${ }^{53}$ (1957) 12 F.S.C. 33 
In Oshilaja $V$. Oshilaja $^{54}$ the court held that in accordance with the decision of the Supreme Court in the Suberu's case, the widow in the instant case could not inherit her deceased husband's estate, and as the deceased intestate died without a child, the court held that the sons of the uterine sisters were entitled to share in the estate to the exclusion of his widow.

The disintegration of the family property could not therefore be avoided if some of the parts of the family land were inherited by a widow as she could not possibly leave the land in her deceased husband's family in the event of her marriage.

The absence of the right to inheritance by widows extends to the administration of intestate estate. In the Ibo case of Ejiamaike V. Ejiamaike ${ }^{55}$ Oputa J, held that a widow of a deceased person had no right under Onitsha customary law to administer the estate of her later husband "especially where there is an "Okpala" (first male issue) of the deceased who was not a mirror. This was implied in the Yoruba case of Aileru \& Ors V. $A n i b i^{56}$ where Jibowu $J$ held under native law and custom, widows cannot administer the estate of their husbands".

According to these decisions, as far as the property in question is the real property of the deceased husband, customary law does not allow his widow to inherit or administer it. However, in recent years, Yoruba customary marriage tends to be more liberal on this issue. This liberal approach was adopted in respect of the administration by widows, of their deceased husband estate. In Re Joseph Asaboro Deceased ${ }^{57}$ the court $^{2}$ appointed a widow to e one of the two administrators of the estate of her deceased husband.

Under the Ibo customary law, property acquired by a married woman after marriage; goes to her husband on her death.

In Nwugege $V$ Adigwe \& Ors, ${ }^{58}$ where the court had to call chiefs to answer the question which the court was faced with. The chiefs asserted that on the death of a married woman, any property which she had acquired before her marriage goes to her own family and not to her husband or his family, but movable properties acquired by the wife before marriage if taken by the wife to her husband's house, goes to the husband or his family on her death, and that property acquired by a married woman after her marriage goes to her husband on her death. The court accordingly held that it was the defendant that was the proper person to administer the decreased woman's estate.

Among the Yoruba's and some other communities, a husband cannot inherit from his wife just as the wife cannot inherit from the husband. If she dies without an issue, her property passes to her siblings. It is also true that a wife cannot inherit property acquired by the husband during separation.

\subsection{INHERITANCE RIGHT OF ILLEGITIMATE CHILDREN}

By the received English Law, a child born out of lawful wedlock, that is, under the Marriage Act or some foreign law which prescribes monogamy, is regarded as illegitimate. This status deprives the child of the right to maintenance and succession in respect of its natural father.

Under customary law, the question of the existence of a status of illegitimacy has been contested by writers. Coker described the position under Yoruba customary law thus:

"It is generally supposed that there is no status of illegitimacy in native law and custom: this is not correct, for there is a status of illegitimacy as opposed to that of legitimacy. The latter entitles the subject ipso facto to succeed to property; the former disentitles the subject from so succeeding, unless his rights are legalized by an acknow3ledgment of paternity' by the father. Generally speaking, a child born in wedlock is legitimate from birth, whereas an illegitimate child can only be legitimated if he was duly acknowledged by his father. It is important to observe that the bastard is so regarded among the Yoruba

\footnotetext{
54 C.C.H.C.J. 30/10/73 pg 11

${ }^{55}$ (1972) 2 E.C.S.N.L.R. pg 11

${ }^{56}$ (1952) 20 N.LR. 46

${ }^{57}$ Suit No Ak/4/70 (unreported) Akure High Court.

58 (1934) ALL NLR 134
} 


\section{as, and is commonly called the Omo Ale, which literally means 'the child of an adulteress} or an unmarried woman'... 59

Dr. Obi after examining the position in Southern Nigeria came to the conclusion that: a child born of an unmarried mother is illegitimate at birth unmarried" being used to include women whose marriages have been legally dissolved. ${ }^{60}$

If an unmarried mother gives birth to a child, some social stigma is usually attached to such a pregnancy; which in Ibo custom is referred to as 'Ime Nkpuke', which literally means 'pregnancy out of the matrimonial home'. The status of that child is regarded as illegitimate. Sometimes where the natural father of such a child has accepted paternity, he may be allowed to claim the child even though he does not marry its mother. This situation is seen to be akin to the principle of legitimation by acknowledgement in Yoruba customary law.

Legitimation is a process by which a child who was born illegitimate acquires legitimate status. The process of legitimation may be achieved by the subsequent marriage of the parents or by the acknowledgment by his natural father.

Acknowledgement simply means the recognition of the paternity of a child by his natural father. Consequently, an illegitimate child may be legitimated by acknowledgment despite the fact that the parents are not married or have never been married.

To constitute acknowledgment, the acts or conduct of the illegitimate child's father must be such as to indicate or establish his acceptance of the child's paternity. It has been held that the maintenance e of a child by his natural father including the payment of school fees constitute acknowledgment. ${ }^{61}$ It should be noted that the principle of acknowledgment does not appear to be universal. For example, under the TIV customary law, acknowledgment is not approved but majority of the native law and custom accepts and approves it.

The necessity to examine the rights of an illegitimate child arises from the fact that the right of an illegitimate child is very controversial. According to Kasumu" "most of the cases on illegitimacy deal with the right of illegitimate child to succeed propert6y... it is in that area that the consequences of illegitimacy are being greatly felt'.

It is a well established rule of law that a child born during the subsistence of a customary or statutory marriage between his/her parents is legitimate. However, where a child is born to a legally married man through extramarital affairs, the 1question of illegitimacy y arises. More often than not, the mothers of this class of children in Nigeria believe that their children, though born outside marriage, have the same inheritance rights to the estate of their father as do the legitimate children of the marriage. This inevitably leads to litigation, during which time the courts, in applying the law attempts to reconcile it with social realities. This recalls the statement that" illegitimacy as a social problem is as old as unsolved as human existence itself. In attempting to find a legal solution, the courts have allowed the strict legal rule to override policy and social considerations. ${ }^{63}$

However, in consideration of the dual marriage system, the Supreme Court Adeyemi V. Bamidele ${ }^{64}$ said that... legitimacy in England is a different concept on legitimacy in Nigeria. The court also held that the status of legitimacy may have different implications according to the system of law referred to and it is appropriate in the context purely and solely of Yoruba customary law to describe a person as an illelgitimate child of the father since even if he was born out of wedlock he would be legitimate if his paternity is acknowledged by the putative father.

In Olulode V. Oviosu, ${ }^{65}$ the learned judge confirmed the principle enunciated in a long line of decisions like Lawal V. Youran, and Bamgbose V. Daniel that there is no issue of illegitimacy in Nigeria once the father has accepted the paternity of the child".

${ }^{59}$ Coker G.B.A. Family Property Among the Yorubas, $2^{\text {nd }}$ Edition (Sweet and Maxwell, London (1966), 266.

${ }^{60}$ Obi; S.N.C. Modern Family Law in Southern Nigeria. (Sweet and Maxwell), London African Universities Press, Lagos, 1966), 294.

${ }^{61}$ Young V. Young (1953) WACA, 19.

62 A.B . Kasumu "Adultery, Acknowledgement and the illegitimate child in Nigeria (1973) U.G.L.I. Vol. 15

${ }^{63}$ N. Rubin and E. Cotran (ed) Annual Survey of African Law (1968) Vol. 1 pg. 45.

64 (1968) 1 ALL NLR 31 PG 37.

${ }^{65}$ Unreported, High Court of Lagos State, Ikeja Judicial Division, $27^{\text {th }} \mid$ Nov., 1981 , Suit No M/133/81 
Under the Yoruba and some other customary law, illegitimate children are accorded the same rights as children who are born in lawful wedlock while in others they are deprived of succession rights. The courts appear to be supporting this reprehensible practice as demonstrated in the case of Onwudinjo V. Onwudinjo ${ }^{66}$ where the court rejected the claim of an illegitimate child to share in the estate of his father on the ground that no evidence had been laid down in support of such claim, but clearly supported a claim made by a child where paternity has been acknowledged.

\section{(c) THE RIGHTS OF AN ADOPTED CHILD}

Adoption of children is very rare in our customary law, it is however common with the English and naturally features in the common law. The position of an adopted child as regard succession is not very clear. It has however been established that the right of an adopted child is inferior to that of the legitimate child. ${ }^{67}$ This view, however is not shared by Nwogugu ${ }^{68}$ According to him, generally, under the customary law, a child adopted takes the names of his adaptor and is regarded as his legitimate child. It is said that he will succeed along with other legitimate children of the adaptor.

Among the Efiks, the procedure for adoption requires the presence of members of the adoptor's family from whom the adoptor formally nominates his/her adoptee. An adoption which fails to conform to this procedure confers no right upon the adopted children. Therefore the right to succeed to any property by any adopted child depends on the validity of the procedure. ${ }^{69}$

For the Yoruba's it has been stated that an adopted child cannot inherit from his/her adoptive parents. However, in the case of Administrator General V. Tuwase ${ }^{70}$ the estate of a Yoruba woman from Ijebu who had died without a child was claimed on one hand by her husband from whom she had been separated for 44 years before her death and on the other hand her adopted child who predeceased her. The claim of the husband was rejected and it was ordered that the descendants including the adopted children of the deceased natural grandfather should take one share each, while her direct descendants that is, surviving adopted child should share per stripes. This suggests that the right of an adopted child is inferior to that of a legitimate or legitimated child. It is not really clear if the adopted child can inherit from his natural parents even if he knows them. But a logical inference will be that since inheritance follows the blood, and since he never has a clear cut right of inheritance from the adoptive parents, he should be able to inherit from the natural parents.

Section 42(1) of the 1999 Constitution provides that:

\section{Criticism Of The Mode Of Inheritance}

"A citizen of Nigeria of a particular community, ethnic group, place or origin, SEX, religion, political opinion shall not, by reason only that he is such a person: (a) be subjected either expressly by or in the practical application of any law in forces in Nigeria or any executive or administrative action of the government, to disabilities or restrictions to which citizens of Nigeria of other communities, ethnic groups, places or origin, sex, religion or political opinion are not made subject”.

Section 42(2) 1999 Constitution equally provides that no citizen of Nigeria shall be subjected to any disability or deprivation merely by reason of the circumstances of his birth. A similar right is guaranteed under Article 2 of the African Charter on Human and Peoples' rights in the following terms:

"Every individual shall be entitled to the enjoyment of the rights and freedom recognized and guaranteed in the present charter without distinction of any kind such as race, ethnic group, colour, sex, language, religion, political or any other opinion national or social origin, fortune, birth or other status".

Article 1 of the UN Convention on the Elimination of ALL forms of Discrimination Against Women (CEDAW) defines discrimination as "any distinction, exclusion or restriction made on the basis of sex in the political, economic, social, cultural civic or any other field".

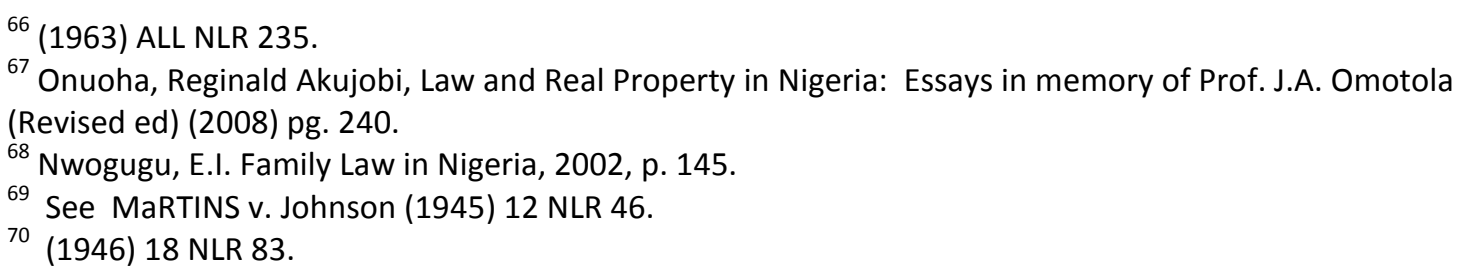


Article 1 further defines discrimination against women as anything that can bring about unequal treatment between men and women in the course of their livelihood. This article groups married and unmarried women together. Article 13 stipulates in part that women have the right to obtain family benefits, while Article 15 states inter alia that women have equal rights with men in matters of law that relate to business contracts. Under Article 16, women are empowered to own and give away their property.

Nigeria having ratified CEDAW treaty is bound by its provisions hence anything to the contrary must be declared null and void. Unfortunately, Nigerian courts have for long sustained some of the customary practices which subjugate women as demonstrated in the case of Nwanya $V$. Nwanya. ${ }^{71}$ The case of Mojekwu V. Mojekwu ${ }^{72}$ has however marked a turning point. The Court of Appeal Per Niki Tobi (as he then was) held as peril repugnant to natural justice, equity and good conscience the Oli-ekpe custom in Ibo land which debases and debars women from inheriting landed property.

According to his lordship:-

"Day after day, month after month and year after year, we hear of and read about customs which discriminate against the womenfolk in the country. They are regarded as inferior to the men folk. Why should this be so. All human beings male and female are born into a free would and are expected to participate freely without any inhibition on grounds of sex. Apart from being unconstitutional, it is an antithesis to the society built on the tenets of democracy which we have freely chosen as a people. We need not travel all the way to Beijing to know that some of our customs including the Nnewi "Oli-ekpe" custom relied upon

on by the appellant are not consistent with our civilized world in which we live today... on my part, I have no difficulty in holding that the oli-ekpe custom of Nnewi is repugnant to natural justice, equity and good conscience. The oli-ekpe custom is one of such customs as it permits the son of a brother of the deceased person to inherit the property of the deceased to the exclusion of the deceased's female children".

The above decision has hindered the realization of equality of rights of both men and women to inheritance under Igbo customary law

Under the primogeniture rule, it is the general rule of customary law that where a landowner dies intestate, his self-acquired property devolves on his children as family property. ${ }^{73}$ The head of the family is the eldest male child of the deceased who occupies the family house and holds same as a trustee of the other children, male or female

In Bini and |Onitsha communities, the deceased property devolves to the eldest son exclusively in accordance with the rule primogeniture under which $\mathrm{h}$ the eldest son in expected in modern times to look after his younger ones and may sell the house over the heads of other children or treat same as if it were his own privatel6y acquired absolute property. Also among the Markis gro7up of the verbe of Northern Nigeria, the rule of ultimogeniture whereby inheritance is by the youngest son, applies to bar other heirs of the decease landowner

The rule of primogeniture on the face it, is unfair to the youngest children of the family who are barred, hence it is repugnant or natural justice, equity and good conscience, ${ }^{74}$ it is equally unconstitutional, unfair and unjust. In Ogiamen V. Ogiamen ${ }^{75}$, the Supreme Court expressed the view that there was nothing wrong with this custom, which is not unknown in some other highly civilized countries of the world. But this case was decided when the agitation for equality of rights had not reached a crescendo.

Although the eldest son in enjoined by custom to provide for the maintenance of his younger brothers, sisters and other relations, he is not strictly accountable to them for his use and enjoyments of the family property. ${ }^{76}$

Although the eldest son, as the head of the family holds no legal estate in the property, chances are that he might use the estate in such a way as to make it empty before he is succeeded by his next brother on his death. At

71 (1987)3 NWLR (Pt 62) 697

72 (1997) 7 NWLR (Pt 512) 283

${ }^{73}$ Suberu V. Sunmonu (1957) 2 FSC 38.

74 That was the view of the court of first instance in Ogiamen V Ogiamen (1967) NMLR 245 @ 247.

751967 Supra

${ }^{76}$ Taiwo V. Dosunmu (1966) N.M.L.R. 94. 
times, the eldest son for the purpose of maintaining peace and harmony gives at his discretion part of the estate to his younger brothers. ${ }^{77}$ It must, however be borne in mind that this discretion exercised at the whims and caprices of the eldest son is not enough to cure that evil inherent in such a custom.

In customary law generally, a husband cannot inherit his deceased wife's share of her family property for the husband is treated as a stranger who is not entitled to share in the family property of which he is not a member. In Caulcrick $V_{\text {Harding }}{ }^{78}$ the deceased landowner life property for his three daughters one of whom was the plaintiff's deceased wife. The plaintiff's husband claimed a third share of the property by virtue of his deceased wife's right to such one-third estate. It was held that he had no such right as the property devolved on the wife's family as family property. A widow is not equally entitled to share in the property of the deceased husband at customary law. ${ }^{79}$ This seemingly unfair practice exists by virtue of an intestacy, in that under native law and custom, devolution of property allows the blood, therefore a wife not being of the blood has no claim to any share. This was the decision in Sogunro Davies V Sogunro. ${ }^{80}$ Exception to this repugnant customary practice is in a situation in which a widow chooses to remain in her husband's house and retain his name, she is to that extent, entitled, notwithstanding that she has no children. This is to ensure her maintenance but she cannot transfer any of the husband's property outright.

Her interest in the house or farmland is merely possessory and not proprietary so that she cannot dispose of it. It is submitted that this custom is repugnant and offends the principle of natural justice, equity and good conscience. This submission is based on the consideration that the wife, during the existence of her marriage and during the deceased husband's life might have labored and toiled to bring about the acquisition of such property together with the deceased husband. It is therefore not only repugnant to natural justice, but also morally repulsive to deprive her ownership of such property.

For even the Holy Bible has written thus: a man shall leave his parents and cleave unto a woman and shall become one flesh". ${ }^{81}$ Why and how can a mortal being dare alter the creation of God. Truly speaking, husband and wife are one body and same blood hence there is the moral need for them to share what belongs to them equally and freely too.

On the other hand, a husband's deprivation of inheritance in his deceased wife's share of her family property is justified. The principle of nemo dat quod non habet aptly applies here. Same condition exists as regards deceased wife's ante nuptial property. Nonetheless, his right of inheritance in his deceased wife's real property depends on whether the wife left any surviving issues, and two, whether the property was acquired before or during overture: but certainly, wife's ante-nuptial property goes to her children jointly and in default of her children goes to her relatives never to the husband, though he has a right over personal property

This customary principle was affirmed in the case of Nwugege $V$ Adigwe ${ }^{82}$. This is an administrative suit from Onitsha in which the claim by the head of the family of a deceased widow for letter of administration of her estate was opposed by her husband's son by another wife. The latter was held to be the proper person to administer the estate. The court rejected another proposition of the customary law of Onitsha laid down by six red cab chiefs who gave evidence in the case. That where a man marries a woman who has a house and lives with her as husband and wife in that ho7use, it goes to the wife's family on her death. The reason by the court for rejecting this proposition was that in laying it down, the chiefs explained that under their custom, it is unheard of that a man marries a woman and lives with her in her house, which is equivalent to accepting the custom that a woman should marry a man and not otherwise.

As regards ante-nuptial property, the general rule is that such property remains property 9of the wife except it is mixed with the property acquired during overture, and where the wife is predeceased by her husband and all her children, the property will go to the husband's relatives. This is so because inheritance of wife's property by her husband in default of issues contradicts the general principle that devolution follows the blood but is explainable by the fact that marriage has the effect of transferring the wife to the husband's patrilineal. This principle accords with the customs of Netembe and Kalabari people where under Iya marriage, the wife and the children have right of inheritance.

\footnotetext{
${ }^{77}$ Nwogugu E.I. op. cit at 412.

78 (1929) 7 NLR 48

79 Nezuanya V Okagbue ors (1963) 1 ALL NLR 352.

80 (1929) 9 NLR @ 79/80;

${ }^{81}$ Genesis chapter 2 verse 24, see also Mark 10:6-9 - "What God has joined together let no man put asunder.

82 (1934) 11 NLR 134.
} 
Among the Yorubas, the Idomas, a husband cannot inherit from the wife just as the wife cannot inherit from him. If she dies without an issue, the property passes to her siblings. A boiling point which requires clarification and justice is the position of customary law that inheritance follows the blood and the issue of property acquired through concerted efforts of both the husband and wife, should the wife not b e accorded a right of inheritance here? It is hereby submitted that this should be an exception to the rule; for to do otherwise will amount to injustice and a contravention of the biblical injunction that "husband and wife are but one flesh".

It will equally violate the above provisions which is against discrimination and deprivation on grounds of sex and Section 43 of 1999 Constitution which stipulates that "subject t to the provisions of this constitution every citizen of |Nigeria shall have the right to acquire and own immovable property anywhere in Nigeria".

A similar right is guaranteed in Article 2 of the African Charter in the following terms:

Every individual shall be entitled to the enjoyment of the right and freedom recognized and guaranteed in the present charter without distinction of any kind such as race, ethnic group, colour, sex, language, religion, political or any other opinion, national or social origin, fortuner, birth or other status.

On the reason why a wife cannot inherit her deceased husband's estate, Jibowu F.

J. in Suberu V. Sunmonu ${ }^{83}$ stated that:

"It is a well settled rule of native law and custom of the Yoruba people that a wife could not inherit her husband's property since she herself is like chattel to be inherited by a relative of her husband".

Earlier, in Sogunro-Davies V. Sogunro-Davies ${ }^{84}$ Beckey J. and stated that Yoruba native law and custom deprived the wife of inheritance rights in her deceased husband's estate because devolution follows the blood.

If a woman is deprived of inheriting her husband's property on this basis, it is only fair and just for a man to be prohibited from inheriting his wife's property because both of them are not of the same blood. In the absence of issues the woman's family should be absolutely entitled to her property where it is shown that the man did not contribute towards the purchase of the property. By this the inequality in the treatment of a widow and a widower will be reduced to the barest minimum.

\section{Conclusion}

Efforts have been made to discuss in details the problems associated with inheritance rights under customary law in Nigeria especially as it relates to discrimination among Yoruba and the Igbo people of Nigeria. Consequently the following reforms are suggested;

\section{(a) ENLIGHTENMENT PROGRAMME:}

Most people are ignorant of the rights afforded them under the statutes and if such laws are to have their desired impact, then it will be expedient to launch extensive e educational as well as legal aid programmes. Legal literacy is an invaluable tool for the empowerment of women because it provides essential information that allows women to exercise their right through channels of legal assistance and action. The Beijing Declaration and platform for action of the fourth United Nations World Conference on women stated that:

"While women are increasingly using the legal system to exercise their rights, in many countries, rights is an obstacle that prevents women from fully enjoying their human rights and attaining equality. ${ }^{85}$

Governmental organizations as well as civil society have always acted as indispensable agents in the protection and promotion of the rights of the vulnerable in the society and continue to do so. Their continued and intensified efforts to promote women's inheritance rights through legal literacy programmes would help to reduce the discriminations which women experience.

83 (1857) Vol F.S.C

${ }^{84}$ (1929) 2 N.L.R.

${ }^{85}$ World Conference on Women, Sept 4-15, 1995 Beijing Declaration and platform for Action 227. 


\section{(b) HARMON IZATION OF THE PRINCIPLES OF NATURAL JUSTICE WITH} CUSTOMARY LAW

The harmonization meant here is like the harmonization of the equitable principles with the common law, so that where there is a lacuna in the customary law application, the principles of natural justice will be applied. Like common law and equity, customary law and princ8iples of natural justices can be harmonized into a single legal system and be applied side by side where necessary, the objective being to supplement the customary law and not to supplant it.

\section{(c) UNIFICATION OF CUSTOMARY LAWS.}

The unification of customary laws in the country will bring about a possible solution to the problem of lack of unity among the various customary laws and practices in Nigeria. It means the assimilation of the customary laws of all major tribes in Nigeria so as to have one unified law.

CODIFICATION OF CUSTOMARY LAW

Codification of the customary law will bring about certainty and sanctity of the law. This is because a society where an individual knows the applicable law, his rights and obligations and punishment for the breach of the law, will certainty command obedience and respect of the law.

Our customary law especially in the area of inheritance is uncertain as demonstrated in the case of Dawodu V. Danmole $^{86}$ where, in the unsuccessful application of one method of distribution, per stripes (Idiigi) will lead to another method (Ori Ojori) per capita.

The process of c codification embraces moral and legal considerations and of course effective co-ordination of both.

\section{(e)OPTION OF WILL}

It is imperative for people to make wills so as to avoid situations whereby their estates will be governed by customary rules of inheritance. A person can dispose of his property in the way and manner he deems fit and proper to any person of his choice and in any proportion as long as it is stipulated in his will.

\section{(f)HARMONIZATION OF RECEIVED ENGLISH LAW AND CUSTOMARY LAW}

Both the received English Law, and customary laws should be harmonized to operate side by side like the Land Use Act which recognizes statutory right and customary right of occupancy.

\footnotetext{
${ }^{86}$ (19458) 3 FSC 46 (1962) 1 ALL NLR.
} 